\section{University of California fined over security breach}

The US Department of Energy has fined the University of California \$3 million for violations related to a security breach at Los Alamos National Laboratory in New Mexico.

In a raid in 2006, police found classified material in the home of a subcontractor who had been scanning lab documents for a work project. The department determined that the University of California's security measures were "deficient" and partly to blame for the violation.

Los Alamos has been hit by a series of security lapses in recent years, causing the energy department to sever an exclusive contract with the University of California that dated back to the Second World War. Since June 2006 the university has managed the lab as part of a broader business consortium.

Spokesman Chris Harrington says that the university is reviewing the final notice and has not yet determined whether to appeal against the ruling.

\section{Blueprint drawn up for Britain's science spending}

Britain needs to invest more in high-tech research and innovation if it is to remain competitive in a globalized economy, says its former science minister. David Sainsbury makes his recommendations in a government-commissioned review of British science and innovation.

The report, entitled The Race to the Top, calls for Britain's Technology Strategy Board to oversee government-funded research councils and make it easier for industry to gain access to research and development funds, with the aim of fostering technological innovation. "Company strategies based on low costs alone will end up in a downward spiral," Sainsbury says.

The recommendations in the report, released on 5 October, will provide a strategic outline for a comprehensive overhaul of government science and other spending announced on 9 October. As Nature went to press, this spending review was expected to include a substantial boost in government funding for research.

\section{Council of Europe votes against creationist teaching}

Creationism is a potential threat to human rights and any attempts to incorporate it into science must be resisted, says the Council of Europe. The council is an intergovernmental body that is responsible for, among other things, the European Convention on Human Rights.

On 4 October, the council's Parliamentary Assembly voted in favour of its member states promoting evolution as "a fundamental scientific theory" and to "firmly oppose the teaching of creationism as a scientific discipline on an equal footing with the theory of evolution". The motion is not binding on the council's 47 member states.

Concerns have been increasing about the promotion of creationism in Europe. The council highlighted a number of campaigns in countries such as Britain, Turkey, France and Russia (see Nature 444, 406-407; 2006).

\section{Conservationists spot flaws in plan to save owl}

Concerned scientists and Democratic congressmen each sent their own letter to the US Department of the Interior on 2 October, protesting against the agency's draft plan to save the northern spotted owl (Strix occidentalis caurina) from extinction.

\title{
Hooke online offers minute details of Royal Society
}

\begin{abstract}
The original pages are too delicate to touch, but now anyone with Internet access can read the writings of Robert Hooke, one of seventeenthcentury Britain's greatest natural philosophers. The Royal Society, of which Hooke was appointed secretary in 1677 , has created an online version of the $£ 1$-million (US\$2-million) notebook that it dramatically rescued from auction in March last year (see Nature 440, 725; 2006).
\end{abstract}

The manuscript contains

Hooke's personal minutes of Royal Society meetings from 1661 to 1691, and provides a glimpse of the scientific discoveries of the age, as well as Hooke's personal spats with other greats such as Isaac Newton. The online version of the manuscript (pictured) can be seen at www.royalsoc.ac.uk.

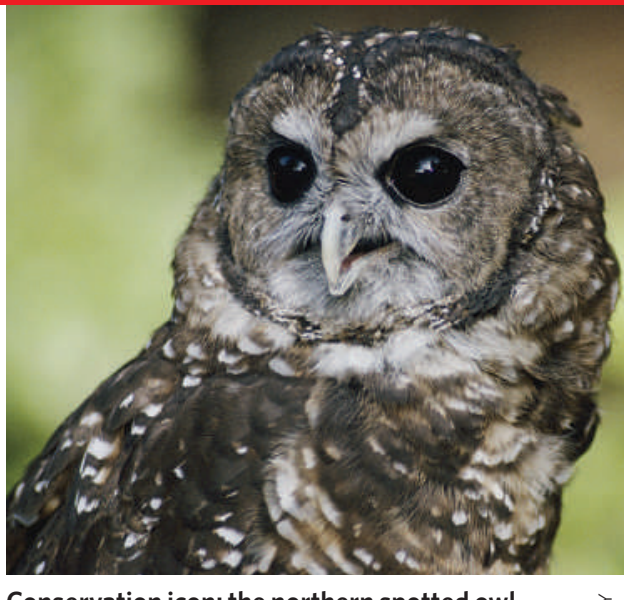

Conservation icon: the northern spotted owl.

The rescue plan for the conservation icon rests heavily on controlling another owl - the barred owl (Strix varia) — that outcompetes its spotted cousin. But the Society for Conservation Biology and the American Ornithologists' Union, both hired as peer reviewers by the government, as well as three owl experts who were also consulted, all felt that this emphasis was strange. They say that habitat loss due to logging is the clear cause of the owl's decline.

Meanwhile, the Government Accountability Office has begun examining several decisions based on the Endangered Species Act that have been criticized by environmentalists, including that on the spotted owl.

\section{India gets high-security lab for human diseases}

India will set up its first high-security facility for handling and doing research with highly infectious organisms that cause diseases in humans.

The US\$25-million biosafety level-4 (BSL-4) lab is to be established on a 2-hectare site in Hyderabad, about 3 kilometres from the Centre for Cellular and Molecular Biology (CCMB). The centre has been given responsibility for setting up the new lab as a national facility.

India already has a BSL-4 lab for animal pathogens in Bhopal, and only last month validated and cleared BSL-3-level labs at five institutions. Details of containment facilities at the defence department's laboratory in Gwalior are not available.

Lalji Singh, director of the CCMB, says the new lab will not do any classified defence work: "The main objective of our facility would be to carry out basic research on the biology of lethal and highly infectious microorganisms."

\section{Correction}

The Business story 'The carbon cycle ride' (Nature 449, 522-523; 2007) should have said that India has more UN-registered carbon-trading projects than China and Brazil combined - not that it has more than China and India combined. 